
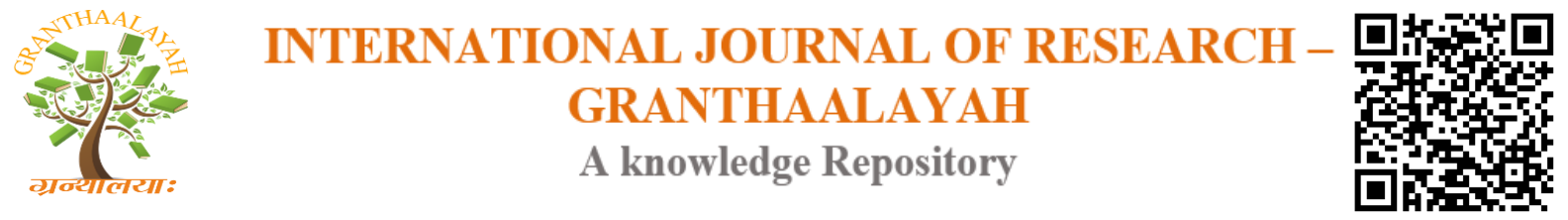

Management

\title{
THE INFLUENCE OF CORPORATE SOCIAL CAPITAL ON EFFICIENCY OF INFORMATION COMMUNICATION TECHNOLOGY SECTOR IN IRAN
}

\author{
Ali Salari ${ }^{1}$, Saudah Bet Sofian ${ }^{2}$ \\ ${ }^{1,2}$ Department of Accounting and Finance, Faculty of Management, UTM, 81310 UTM Johor \\ Bahru, MALAYSIA
}

DOI: https://doi.org/10.29121/granthaalayah.v4.i9.2016.2551

\section{ABSTRACT}

The difference between market value and book value of a company is attributed to Intellectual Capital (IC). This difference is as an Indicator to recognize the efficiency or inefficiency of a company. Therefore, the effective use of IC is one of the most important factors on company efficiency. IC is a group of knowledge assets and one of these knowledge assets is Corporate Social Capital (CSC). CSC is a kind of intangible assets and it is argued that the main dimensions of CSC are relevant to IC. In this paper, CSC is defined as the characteristics of the IC, Corporate Reputation (CR), and Structural Social Capital (SSC). The problems that this study has focused on are (i) absence of known and clear mechanism for assessing the impact of CSC on company efficiency, (ii) applying an indicator to assess the efficiency instead applying a set of indicators, and (iii) disregard of financial soundness as an effective element on company efficiency. Base on the problem of the study, the objectives of this study are (i) to examine the relationship between CSC and company efficiency, (ii) to determine the effects of each one of CSC's components on company efficiency, and (iii) to examine the interaction effects of variable or variables that have unexpected results on company efficiency. The data were analyzed used by (i) Multiple Regression, (ii) Post Hoc Analysis (PHA), and (iii) Principal Component Analysis (PCA). The results showed that (i) CSC has an important influence on company efficiency, (ii) Centrality, Human Capital and Financial Soundness have positive influence on company efficiency, and (iii) Research Intensity and Internal Capital have negative influence on company efficiency. Lastly, Financial Soundness can counteract the negative influences of Research Intensity and Internal Capital on company efficiency. The results of the study suggested that (i) added value of CSC to different companies in the ICT sector showed be recognized (ii) showed a theoretical model for CSC, and (iii) External Capital is substituted by company Centrality in IC. The findings of the study also show the importance of IC and CSC on company efficiency and it is recommended that CSC should be considered as an important element on company efficiency that has influence on financial statements. 


\section{Keywords:}

Corporate social capital; Company efficiency; Intellectual capita; Structural Social Capita; Intangible Assets; Corporate Reputation.

Cite This Article: Ali Salari, and Saudah Bet Sofian, "THE INFLUENCE OF CORPORATE SOCIAL CAPITAL ON EFFICIENCY OF INFORMATION COMMUNICATION TECHNOLOGY SECTOR IN IRAN" International Journal of Research - Granthaalayah, Vol. 4, No. 9 (2016): 170-190.

\section{INTRODUCTION}

Corporate Social Capital (CSC) is a Social Capital (SC) subject that can be defined in relation to public or private companies. Leenders \& Gabbay (1999) developed the meanings, viewpoints and the applications of social capital as they applied it to commerce and provided some useful information about CSC like, concepts, theories and the application of CSC to business. Today, a broad opinion of the market contains a mixed net of inter-firm activities. CSC is an intangible asset and companies cannot measure it in straightforward accounting phrases. Overall, CSC and its effect on company's efficiency is the focus of this paper.

Efficiency signifies a level of performance that describes a process that uses the lowest amount of inputs to create the greatest amount of outputs. Efficiency relates to the use of all inputs in producing any given output, including personal time and energy. Efficiency is a measurable concept that can be determined using the ratio of useful output to total input. In todays' business environment, relation resources, such as social capital like an intangible asset that is created through social relations can be leveraged to facilitate achieve and sustain a competitive advantage with business partner and governing agencies (Gulati \& Gargiulo, 1990) are viewed as strategic resources. However, despite the growing empirical and theoretical research on social capital, significant gaps appear in the literature. social capital is defined as the characteristics of the social organization, such as networks, norms and trust, which can increase efficiency by promoting coordinated actions (Putnam, 1995). In management terms, CSC is the social capital that develops between the family members, especially within family firms (Arregle, 2008). Thus, the specificity of family companies is based on the unique coexistence of two forms of social capital which belongs to the economic sphere (Arregle, 2008). The dimension of a company's social capital involves the commercial relations with the different stakeholders, the employees, suppliers, customers, creditors, etc., that all of them are intangible assets to a company and all the social values, beliefs and behaviors adopted by the companies (Hirigoyen, 2009).

The value of an Intellectual Capital (IC) can be seen when market value is different from the net value of tangible assets. The net difference between market value and book value is named Market Value Added, which has been described as the influence of IC. The concepts of IC cannot be limited only to terms used in traditional accounting. In fact, they are defined as a set of nonphysical assets that create added market value of a firm's stock price. In general, there has not been a consensus on a possible explanation of IC, whereas the imprecise ways to measure the assets have made it impossible to provide a specific evaluation of IC (Pike \& Roos, 2004). Sveiby \& Risling (1997) performed one of the early researches to characterize IC. They identified that the three major classes of IC are External Capital (EC), Human Capital (HC), and 
Internal Capital (INC). However, international guidelines or standards have not been presented yet (Zambon, 2003). Another early research to characterize IC is a scorecard approach (Norton, 2001). The more important problem is that IC scorecards have not been adopted in a broad manner (Ricceri, 2008). Furthermore, collecting and comparing IC components is very expensive, and interpreting them consistently is difficult. As a result, Johanson (2003) suggested that the effect of IC elements should be minimized in management decisions. One of the main difficulties in measuring intangibles in the common approaches for measuring tangible assets is that IC is by nature unclear and indeterminate. Therefore, in order to appreciate the effects of tangible and IC on value creation, their internal flows and interactions should be identified (Ricceri, 2008).

Moreover, the purpose of managing intangibles is the development of IC indexes and creates a scale for IC efficiency. One of the simplest scales for measuring the book and market value is Market-to-Book value (P/B). Lev (1999) suggested index knowledge creation and another researcher, Low (2000), provided two indices; value creation and knowledge capital. These are the most important measures in this field. Although, a narrower application of the index is better to help managers and organizations, but an IC indicator is useful only when it provides a leadership platform for managers to enhance intangible effects. One of the most important areas of diversity between the organizational view and accountant theorists towards the notion of intangible is external and internal stakeholders and one point of difference between the organizational theorists "view of intangible (e.g. Sveiby, 1997) and the accountants view (e.g. Lev, 2001) is the focus on internal versus external stakeholders. The ability to measure IC valuation in firms is important to show its significance in analyzing market performance. Since the concept of social capital is considered like an evaluation representative for net market and as an index. Creating social networks and social capital in societies is like a surrounding marketplace that is fully connected by official and unofficial components (Burt, 2000). One of the study's aims is to scrutinize CSC, which is determined by public or private section organizations by studying social capital (Leenders \&Gabby, 1999).

Furthermore, the core focus of this study is on the Iranian Information Communication Technology (ICT) companies. The most important reason for choosing ICT companies is their fast growth in the last 20 years (Gallagher \& Miller 1991). The key feature for this growth is that they do not need high capital and tangible assets, because these companies have more IC and, hence they are more appropriate for this study. The most significant asset for ICT companies is the professional employees who are the Human capital and Human capital is an IC component. ICT companies need more social capital than other sectors and high level of social capital means more value, because, they usually do not produce physical products (Honig, Lerner \& Raban, 2006). Thus, the lack of researches of IC effects on Iranian ICT companies and the aforementioned reasons about IC, social capital and intangible assets in them, are the main factors for choosing Iranian ICT companies for this study.

The collision of a number of market phenomena has presented the motivation for the choice and conduct of this study. The focus of this study is on CSC's impact on company efficiency and this issue that, which CSC components has influence on company efficiency (William, 2004; WannYih, Man-Ling \& Chih-Wei, 2008). The positive relationship between CSC and company efficiency is one of the important issues that can have positive effect on the company, but, the 
mechanisms that constitute this relationship are not yet well-known and also the effects of CSC's elements are not yet clear (Orlitzky, 2003). On the other hand, the previous empirical researchers have usually used only a single efficiency measure of types of efficiency measures like Return On Investment, share price, sales volume or earning. The use of a single efficiency measure cannot provide a clear perspective of overall company efficiency. Therefore, to consider the role of a single index on company efficiency in most of previous studies on SCS field is one of the other problems.

One of the other issue in most previous studies about CSC's elements on company efficiency is focus only on positive effects of IC, while, the conditions of a company is as an important element. Sometimes the conditions of company determinate the positive or negative roles of IC's elements on company efficiency. Therefore, disregard the conditions of a company and excessive attention on positive effects of IC elements without considering company's conditions is one of the other problems in previous studies.

In the last, considering the role of Financial Soundness (FSIs) on company efficiency is ignored by the previous researchers. Forasmuch as Financial soundness can be measured by accounting indexes (Eidleman, 1995), Perhaps this is a reason for ignoring Financial soundness as intangible assets. Therefore, disregard to Financial soundness as an effective element on company efficiency is one of the other problems that has been displayed by this study. Therefore, considering the problems includes the role of CSC and its elements on company efficiency, survey the positive or negative effects of IC's elements on company efficiency, and survey the role of Financial soundness on company efficiency, are the issues that this study addressed to them.

The purpose of this study is to obtain qualitative results from a sample database of Iranian ICT companies to achieve the objectives of the study. The objectives of this investigation are listed in following. The unit of the study is company and the specific scope of this study is related to ICT companies and the population is Iranian-manufacturing companies under ICT sector.

i. To survey the influence of CSC on company efficiency.

ii. To determine the influence of each one of CSC's components on company efficiency.

iii. To determine the variables with interaction effects.

iv. To survey the impacts of interaction variables on company efficiency.

According to the definition provided by Sekaran (2000), a theoretical framework is the foundation on which the entire research study is based on. Saunders (2007) stated that researchers will likely analyses data using a theoretical framework. The conceptual framework of this study is built upon the Agency Theory and Tobin Q Theory. This framework shows the examines of the relationship between CSC components as dependent variables and company efficiency as independent variables with considering three control variables include size of company (Size), profitability or loss-making the shares of company (Profitability), and industry include software or non-software sector. 


\section{MATERIALS AND METHODS}

This study is on the relationship between CSC and company efficiency. The effects of CSC and IC (intangibles assets) in company efficiency, and the gap between market and book values. The intent is to apply the methods and analytical techniques used by other investigators in this study. The hypotheses are drawn for examining the CSC and its components effects on company efficiency. The study has five hypotheses related to the non-financial as independent variables of CSC and the financial as dependent variables of company efficiency. The non-financial variables in this study are Human capital, Internal capital, Centrality, Absorptive Capacity, and Financial soundness. The financial variables are Return On Investment (ROI), Total Shareholder Return (TSR), and Tobin's q (Tobin Q), and all obtained from Iranian ICT Companies. Thus, the Hypothesis Model is built on the five concepts of IC, CSC, Reputational Capital, Structural Social capital, and Company Efficiency. The Hypotheses of this paper are illustrated in Table 1.

Table 1: Hypotheses of the Investigation

\begin{tabular}{ll}
\hline No. & Hypotheses \\
\hline $\mathrm{H}_{1}$ & Centrality is positively associated with company efficiency \\
$\mathrm{H}_{2}$ & Absorptive Capacity is positively associated with company efficiency \\
$\mathrm{H}_{3}$ & Human Capital is positively associated with company efficiency \\
$\mathrm{H}_{4}$ & Internal Capital is positively associated with company efficiency \\
$\mathrm{H}_{5}$ & Financial Soundness is positively associated with company efficiency \\
\hline
\end{tabular}

Social capital is distinguished between quantitative aspect or structural Social capital and qualitative aspect or non-structural Social capital (Borgatti \& Foster, 2003; Borgatti \& Jones,1998). Base on this definition and study about relationship between IC (petty \& Guthrie, 2000), Corporate Reputation (Shanley \& Fombrun, 1990) and Structural Social Capital (Borgatti, 1998), the components of CSC are identified as a theoretical model in Fig. 1. The first aspect is Structural Social Capital as a company's partnership and alliances. The position of a company in a network is determined by the nature of its joint ventures and alliances and the contribution of market positioning on market efficiency is a unique contribution of this study. The second aspect of CSC is Non-Structural Social Capital that is formulated as company's Corporate Reputation. Corporate reputation in turn is represented by externally visible of IC components include External Capital, Human capital and Internal capital together with company's Financial Soundness. The important subject is replacement of Centrality with External Capital, because both of them refer to external connections of firm, but Centrality provide company's situation in a network with relationships, therefore Centrality provide a more comprehensive concept than external capital for companies in a network. According to the definitions, the conceptual framework of this study is built upon the Agency Theory and Tobin Q Theory that illustrated in Fig.2. This framework shows the examines of the relationship between CSC components as independent variables and company efficiency as dependent variables with considering three control variables. 


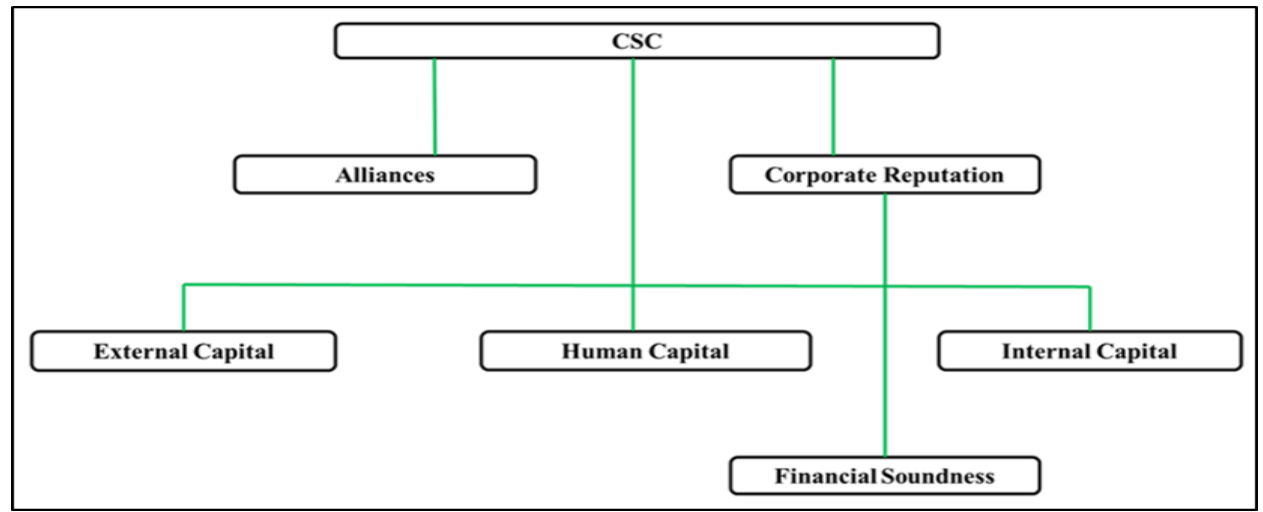

Figure 1: Theoretical Model of CSC
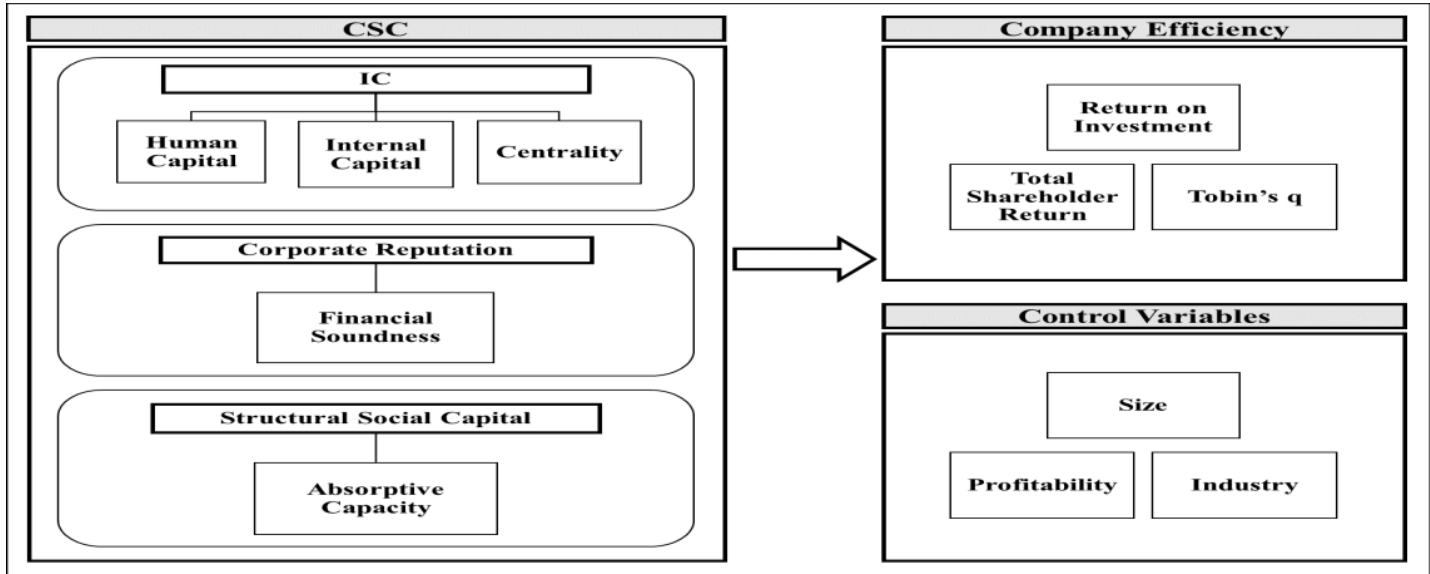

Figure 2: Research Framework

Three groups of variables based on the research framework are designed by this study. These groups of variables include;

- Dependent Variables based on financial indexes

- Independent Variables

- Control Variables

Table 2: Variables of the study

\begin{tabular}{ll}
\hline No. & Variables \\
\hline & Financial variables \\
1 & Total Shareholder Return (TSR) \\
2 & Return on Investment (ROI) \\
3 & Tobin's q (Tobin Q) \\
& Non-financial variables \\
1 & Human Capital (HC) \\
2 & Absorptive Capacity (RES) \\
3 & Internal Capital (INC) \\
4 & Network Centrality (CENT) \\
5 & Financial Soundness (FSIs) \\
\hline
\end{tabular}




\begin{tabular}{ll}
\hline & Control variables \\
1 & company Size (SIZE) \\
2 & profitability (P\&L) positive and negative \\
3 & sub industry sector (IND) software company and non-software \\
& company
\end{tabular}

After identification of variables, the data for each variable are extracted from these techniques. The all data in this study are secondary data. Expect human and internal capital, all data are extracted from financial statement.

A. Return On Investment (ROI): is extracted from financial statement. ROI $=$ Profit Margin * Circulating Assets

B. Total Shareholder Return (TSR): is extracted from the share or stock price of a company in the market.

$\mathrm{TSR}=($ Price End - Price Begin + Dividends $) /$ Price Begin

C. Tobin's q (Tobin Q): is extracted from the financial statement.

Tobin Q $\approx$ Equity Market Value / Equity Book Value

D. Absorptive Capacity (RES): The Research and Development (R\&D) is index for calculating Research intensity. It is extracted from financial statements.

RES $=$ Cost of Research and Development / Total Sell

E. Financial Soundness (FSIs): is as an indicator for financial health and soundness of a company. The Altman Z-score is index for calculating Financial soundness and it is extracted from financial statements.

$\mathrm{Z}=0.717 * \mathrm{X}_{1}+0.847 * \mathrm{X}_{2}+3.1 * \mathrm{X}_{3}+0.42 * \mathrm{X}_{4}+0.998 * \mathrm{X}_{5}$

$\mathrm{X}_{1}=$ Liquidity Ratio $=$ Working Capital $/$ Capital Total Assets

$\mathrm{X}_{2}=$ Profitability Ratio $=$ Retained Earning $/$ Total Assets

$\mathrm{X}_{3}=$ leverage Ratio $=$ EBIT $/$ Total Assets

$\mathrm{X}_{4}=$ Solvency Ratio $=$ Book Value of Share $/$ Book value of Debts

$\mathrm{X}_{5}=$ Activity Ratio $=$ Sales $/$ Total Assets

F. Social Network Analysis (SNA): is a measure to determine the company situation in a network. Degree centrality is an index for calculating company situation.

Degree Centrality $=\sum_{j=1}^{\mathrm{N}} \mathrm{Rij}$

$\mathrm{N}=$ Number of connection with buyers and sellers

$\mathrm{R}_{\mathrm{ij}}=$ Amount of deal between company and a buyer or seller

G. Human Capital (HC) and Internal Capital (INC): The measuring Human capital and Internal capital is done based the questionnaire. the questions are created by a classification of Han $\&$ Han (2004) for human and internal capital. The Analysis Cronbach's alpha $(\alpha)$ is chosen for Reliability of questions.

The analysis methods that is chosen for this study includes;

1) Questionnaire is chosen to analyses qualitative data of Human Capital and Internal Capital.

2) Ranking Scale 
3) Cronbach's Alpha Analysis ( $\alpha$ ) is chosen to measure the reliability of questions about internal and human capital.

4) Pearson Correlation Coefficient (PCC) is chosen to determine the connection, type and direction of the relationship between variables.

5) Factor Analysis (FA) is chosen to detects latent variables that summarize variability among several variables.

6) Principal Component Analysis (PCA) is chosen to reducing the number of variables and finding the significant correlation between structures.

7) skewness and kurtosis are chosen as a way for showing the normality of data.

8) Hypotheses Testing Method, Hypothesis tests are part of the basic methodological toolkit of social and behavioral scientists.

9) Post Hoc Analysis (PHA) is chosen as a stepwise multiple comparisons procedure used to identify sample means that are significantly different from each other.

10) Interview Method, Interview method is chosen for measuring reliability and creditability the extracted results for hypotheses.

After extracting data for each of the variables, the normalizing of data is tested and it is shown that none of the selected variables do not have a normal distribution. The data of variables need to be normal, therefore, the transfer of data is used for normalization of data for multivariate analysis. Hence, the variables in this study for hypothesis test are transferred by rank transformation. Relation of Bi-variate for major variables is done and shown several statistically correlations significant. The correlation significant are chosen in the level so that avoid of singularity issues. The alignment of data with the theory using statistical classification method as well as, clustering the measured variables using Factor Analysis is the next step. Varimax Rotation set extraction of principal factors for the five independent variables. The solution involves the eigenvalues and eigenvectors of the variance and covariance matrix. Hypotheses are built up through four models that The first model addressing to examine the role of Centrality on company efficiency. In the second model, Research intensity is added and provided a better concept of CSC. CSC is taking into account a capacity of company to absorbed and developed knowledge and information from alliances. Components of IC including Human capital and Internal capital are added in the third regression model and come with an enriched version of Structural Social Capital. The last and the fourth model added Financial soundness with a representation of Corporate Reputation. The concept of CSC is added to this model for purposes of regression analysis. The regression models are illustrated in Table 3.

Table 3: Stepwise Regression Models

\begin{tabular}{|c|c|}
\hline & Regression Models \\
\hline $\mathrm{H}_{1}=$ & $\begin{array}{l}\text { Perf }_{\text {ROI; }} \\
\text { Perf }_{\text {Tobin's q; }} \\
\text { Perf }_{\text {TSR }}=b_{0}+b_{1} \text { CENT }+b_{2} \text { SIZE }+b_{3} \text { IND }+b_{4} P \& L+e\end{array}$ \\
\hline $\mathrm{H}_{2}=$ & $\begin{array}{l}\text { Perf }_{\text {ROI; }} \\
\text { Perf Tobin's } q \\
\text { Perf }_{\text {TSR }}=b_{0}+b_{1} \text { CENT }+b_{2} \text { RES }+b_{3} \text { SIZE }+b_{4} I N D+b_{5} \text { P\&L }+e\end{array}$ \\
\hline $\mathrm{H}_{3}=$ & $\begin{array}{l}\text { Perf }_{\text {ROI; }} \\
\text { Perf }_{\text {Tobin's q; }} \\
\text { Perf }_{\text {TSR }}=\mathrm{b}_{0}+\mathrm{b}_{1} \mathrm{CENT}+\mathrm{b}_{2} \mathrm{RES}+\mathrm{b}_{3} \mathrm{HC}+\mathrm{b}_{4} \mathrm{INC}+\mathrm{b}_{5} \mathrm{SIZE}+\mathrm{b}_{6} \mathrm{IND}+\mathrm{b}_{7} \mathrm{P} \& \mathrm{~L}+\mathrm{e}\end{array}$ \\
\hline
\end{tabular}




$$
\begin{aligned}
\mathrm{H}_{4}= & \text { Perf }_{\text {ROI; }} \\
& \text { Perf Tobin's } ; \\
& \text { Perf }{ }_{\text {TSR }}=\mathrm{b}_{0}+\mathrm{b}_{1} \text { CENT }+\mathrm{b}_{2} \mathrm{RES}+\mathrm{B}_{3} \mathrm{HC}+\mathrm{b}_{4} \mathrm{INC}+\mathrm{b}_{5} \text { Zscore }+\mathrm{b}_{6} \mathrm{SIZE}+\mathrm{b}_{7} \mathrm{IND}+\mathrm{b}_{8} \mathrm{P} \& \mathrm{~L}+\mathrm{e}
\end{aligned}
$$

The last step to analyzing data is to identify the variables with interaction effects, therefore the Post Hoc analysis is done for identify and analysis of variables and interaction effects. The interaction effects of variables are identified after regression analysis of model 1 to 4.

\section{RESULTS AND DISCUSSIONS}

Based on the explain of human and internal capital, the qualitative data is scored convert to quantitative data. The both of human and internal capital are divided to seven questions and this division is resource for questions providing. The Analysis Cronbach's alpha $(\alpha)$ is chosen for Reliability of questions. After the questions analysis, the reliability correlation is equal to 0.71 and this proved the trust to questions that created for measuring human capital and internal capital. The percent and score area in Table 4 and 5 are extracted from the results of the questionnaire for human capital and internal capital.

Table 4: The Mean Score and Score Area for Components of Human Capital

\begin{tabular}{lccl}
\hline Human Capital Components & $\begin{array}{c}\text { Mean } \\
\text { Score }\end{array}$ & Percent of Score & Score Area \\
\hline Individual Level Knowledge & 7.727 & $+77 \%$ & Agree to Strongly Agree \\
Competence & 2.727 & $+27 \%$ & Neutral to Agree \\
Leadership Ability & 3.363 & $+34 \%$ & Neutral to Agree \\
Risk Taking and Problem Solving & 0.727 & $+7 \%$ & Neutral \\
Capability & 1.919 & $+19 \%$ & Neutral to Agree \\
Education & 4.818 & $+48 \%$ & Agree \\
Experience & 9.089 & $+91 \%$ & Strongly Agree \\
\hline
\end{tabular}

Table 5: The Mean Score and Score Area for Components of Internal Capital

\begin{tabular}{lccl}
\hline Internal Capital Components & Mean Score & Percent of Score & Score Area \\
\hline Mission Vision & 0.181 & $+1.8 \%$ & Neutral \\
Strategical Value & 1.181 & $+18 \%$ & Neutral to Agree \\
Working Systems & 8.181 & $+81 \%$ & Strongly Agree \\
Culture & 2.276 & $+22 \%$ & Neutral to Agree \\
Management System & 6.727 & $+67 \%$ & Agree to Strongly Agree \\
Use of Knowledge & 5.363 & $+53 \%$ & Agree \\
Database & 0.363 & $+3.6 \%$ & Neutral \\
\hline
\end{tabular}

Table 4 illustrated that individual level knowledge and experience are achieved to the biggest scores and this is the reason for importance of individual skills and experiences for a company. On other hand, the least score belonged to risk taking and problem solving. The reason of this the least score may be the dependency of risk taking and problem solving to managers or company and it is not clearly as a skills of employees. But overall, the mean scores of total components illustrated a positive view from the companies and managers to human capital. 
The scores that extracted from the mean scores of questions scores about components of internal capital are converted to percentage and illustrated in Table 5. The results show the importance of working system and management systems to companies and managers for assessments the effects of internal capital's components. On other hand, the database and mission vision are with least scores in between the components. The reasons of these components least scores may be to no significant of them from internal capital view.

In the data descriptive analysis, it is shown that none of the selected variables do not have a normal distribution. The data of variables need to be normal, therefore, the transfer of data is used for normalization of data for multivariate analysis. CSC latent variables are included as Intellectual Capital (IC), Structural Social Capital (SSC), Corporate Reputation and Corporate Social Capital (CSC) that are defined in identified measured variables. Based on the discussions, a theoretical model for CSC formula is extracted. The alignment of data with the theory using statistical classification method as well as, clustering the measured variables using Factor Analysis are described in continue.

Varimax Rotation set extraction of principal factors for the five independent variables. The solution involves the eigenvalues and eigenvectors of the variance and covariance matrix. It is going to let $\lambda_{1}$ through $\lambda_{\mathrm{p}}$ denote the eigenvalues of the variance and covariance matrix. These are ordered so that $\lambda_{1}$ has the largest eigenvalue and $\lambda_{p}$ is the smallest. $\quad \lambda_{1} \geq \lambda_{2} \geq \lambda_{3} \geq \ldots \geq \lambda_{p}$ It is also going to let the vectors e1 through ep denote the corresponding eigenvectors. It turns out that the elements for these eigenvectors will be the coefficients of our principal components. $\mathrm{e}_{1}, \mathrm{e}_{2}, \ldots, \mathrm{e}_{\mathrm{p}}$

The variance for the $i$ th principal component is equal to the $i$ th eigenvalue. Variance: $(\mathrm{Yi})=\operatorname{var}\left({ }_{\text {ei } 1} \mathrm{X}_{1}+{ }_{\mathrm{ei} 2} \mathrm{X}_{2}+\ldots\right.$ eip $\left.\mathrm{X}_{\mathrm{p}}\right)=\lambda_{\mathrm{i}} \operatorname{var}\left(\mathrm{Y}_{\mathrm{i}}\right)=\operatorname{var}\left({ }_{\mathrm{ei} 1} \mathrm{X}_{1}+{ }_{\mathrm{ei} 2} \mathrm{X}_{2}+\ldots\right.$ eip $\left.\mathrm{X}_{\mathrm{p}}\right)=\lambda_{\mathrm{i}}$

Moreover, the principal components are uncorrelated with one another.

Covariance $\left(\mathrm{Y}_{\mathrm{i}}, \mathrm{Y}_{\mathrm{j}}\right)=0$

The variance-covariance matrix may be written as a function of the eigenvalues and their corresponding eigenvectors. This will be useful when the study investigates the topics under factor analysis. It is defined in terms of the population variance and covariance matrix which is unknown. However, the matrix is estimated to the sample variance. The default eigenvalue $<1$ as the threshold is used for clustering the variables into two factors. These clusters of the independent variables are as supporter for cohesive concept of CSC.

Table 6: Factor Analysis Selection of Two Factors

\begin{tabular}{lll}
\hline & \multicolumn{2}{c}{ Components } \\
\cline { 2 - 3 } Factor Loadings & 1 & 2 \\
\hline Centrality (CENT) & $\underline{0.861}$ & -0.57 \\
Research Intensity (RES) & 0.227 & $\underline{0.869}$ \\
Human Capital (HC) & $\underline{0.712}$ & -0.105 \\
Internal Capital (INC) & $\underline{0.849}$ & 0.924 \\
Financial Soundness (FSIs) & $\underline{0.36} \underline{8}$ & $\underline{\underline{-0.463}}$ \\
\hline
\end{tabular}


The results of Table 6 suggested that IC (Human Capital and Internal Capital) and Centrality can be represented by a single factor and abundance between Centrality and external capital is suggested by theoretical model. Results demonstrate external capital can be substituted by Centrality. Therefore, Human Capital, Internal Capital and Centrality can construct the new formula for Intellectual Capital (IC). Based on the results in Table 6, Research intensity (Absorptive Capacity) cannot be considered a sub component in the new IC formula and Corporate reputation formulated of two different factors including IC and Financial soundness (Z-score). The integrated construct of CSC is made up of Human capital, Internal capital, Centrality, Research intensity and Financial soundness. The CSC framework in Fig. 2 created some confirmation of the guess about CSC formula. While this results can be used for other studies relating to different concepts of IC and CSC.

The hypotheses tests are executed for company efficiency measures of Total Shareholder Return, Return On Investment and Tobin's q, and including control variables for Size, Industry sector and Profitability. The results have shown control variables play a significant role as predictors for company efficiency scenario, therefore control variables are investigated for all models. Stepwise regression is used to introduce all models from model 1 to 4 step at a time, statistical significance is indicated at the $\mathrm{p}<0.01, \mathrm{p}<0.05$, and $\mathrm{p}<0.1$ level for 2 -tailed tests. The equivalent significant levels should be 1-tailed test as the hypotheses predict directional influence. Therefore, significant value level of statistical variables shown in at least value of $\mathrm{p}<$ 0.05 level. The 1-tailed test provides more power to detect an effect in one direction by not testing the effect in the other direction. The changes in adj $R_{2}$ (Adjusted $R_{2}$ ) is as measure for identify the explanatory power from model 1 to 4 . The changes in adj $R_{2}$ in regression models include control variables are illustrated by $\Delta$ adj $R_{2}$ and changes in adj $R_{2}$ is indicative as statistically significant results.

As noted, the first objective is about the relationship between CSC and company efficiency and the second objective is about the influences percent of the CSC's models on company efficiency. To achieve these goals, the regression analysis is done for four models of CSC based on control and independent variables for each dependent variable. The results are presented for objective the number one, and the influence percent of each models is presented for objective number two. Table 7 illustrated the effectiveness of CSC on company efficiency and the Influence Percent of each models on the company efficiency is illustrated in Table 8.

Table 7: Effectiveness of CSC Models on Company Efficiency

\begin{tabular}{ll}
\hline Models & $\begin{array}{c}\text { Company } \\
\text { Efficiency }\end{array}$ \\
\hline Model $1=\mathrm{b}_{0}+\mathrm{b}_{1}$ CENT $+\mathrm{b}_{2}$ SIZE $+\mathrm{b}_{3}$ IND $+\mathrm{b}_{4}$ P\&L $+\mathrm{e}$ & + \\
Model $2=\mathrm{b}_{0}+\mathrm{b}_{1}$ CENT $+\mathrm{b}_{2}$ RES $+\mathrm{b}_{3}$ SIZE $+\mathrm{b}_{4}$ IND $+\mathrm{b}_{5}$ P\&L $+\mathrm{e}$ & + \\
Model $3=\mathrm{b}_{0}+\mathrm{b}_{1}$ CENT $+\mathrm{b}_{2}$ RES $+\mathrm{b}_{3} \mathrm{HC}+\mathrm{b}_{4}$ INC $+\mathrm{b}_{5}$ SIZE $+\mathrm{b}_{6}$ IND $+\mathrm{b}_{7} \mathrm{P} \& \mathrm{~L}+\mathrm{e}$ & + \\
Model $4=\mathrm{b}_{0}+\mathrm{b}_{1}$ CENT $+\mathrm{b}_{2}$ RES $+\mathrm{B}_{3} \mathrm{HC}+\mathrm{b}_{4}$ INC $+\mathrm{b}_{5}$ Zscore $+\mathrm{b}_{6}$ SIZE $+\mathrm{b}_{7} \mathrm{IND}+\mathrm{b}_{8} \mathrm{P} \& \mathrm{~L}+\mathrm{e}$ & + \\
\hline
\end{tabular}

Tables 7 and 8 illustrated the numerical outcomes and the results show CSC significantly predicts all company efficiency measures at the $\mathrm{p}<0.01$ level. The results also show increasing in the explanatory power of the CSC's model elements beyond the control variables differed, depending on company efficiency measure. For Return On Investment in the panel A, the panel 
increasing in Adj R-squared was minimal, though statistically significant for the last two models, which added Human capital and Internal capital that added $0.3 \%$ explanatory power and Zscore added $0.6 \%$ explanatory power, is statistically significant at the $p<0.01$ level.

Table 8: Influence Percent of CSC Models on Company Efficiency

\begin{tabular}{|c|c|c|c|c|c|}
\hline \multirow[t]{2}{*}{ MODELS } & \multicolumn{3}{|c|}{ Percent of Financial Variables } & \multirow{2}{*}{$\begin{array}{l}\text { Impact Percent on } \\
\text { Financial } \\
\text { Variables }\end{array}$} & Average Percent of CSC's \\
\hline & ROI & Tobin Q & TSR & & $\begin{array}{l}\text { Impacts on Company } \\
\text { Efficiency }\end{array}$ \\
\hline Model 1 & 84.94 & 64.02 & 1.18 & $50.0466 \%$ & $50 \%$ \\
\hline Model 2 & 85.79 & 65.79 & 3.04 & $50.696 \%$ & $50.5 \%$ \\
\hline Model 3 & 85.91 & 65.93 & 6.07 & $51.316 \%$ & $51.3 \%$ \\
\hline Model 4 & 86.04 & 71.09 & 13.26 & $55.710 \%$ & $55.7 \%$ \\
\hline Controls & 84.89 & 63.01 & 1.02 & $49.640 \%$ & $49.6 \%$ \\
\hline
\end{tabular}

For Tobin Q increasing in explanatory power added by CSC elements over control variables is $6.2 \%$, which is statistically significant at the $\mathrm{p}<0.01$ level. The majority of $6 \%$ increase is created by the addition of the Z score. For Total Shareholder Return, CSC elements added 13\% to the explanatory power over the control variables. An increase of $1.9 \%$, is added by Research intensity $1.9 \%$, Human capital and Internal capital added $4.2 \%$, and $\mathrm{Z}$ score added $7.1 \%$, while each change being statistically significant at the $\mathrm{p}<0.01$ level.

The Adjusted R-squared that show the explanatory power from model 1to 4 is illustrated in Fig. 3.

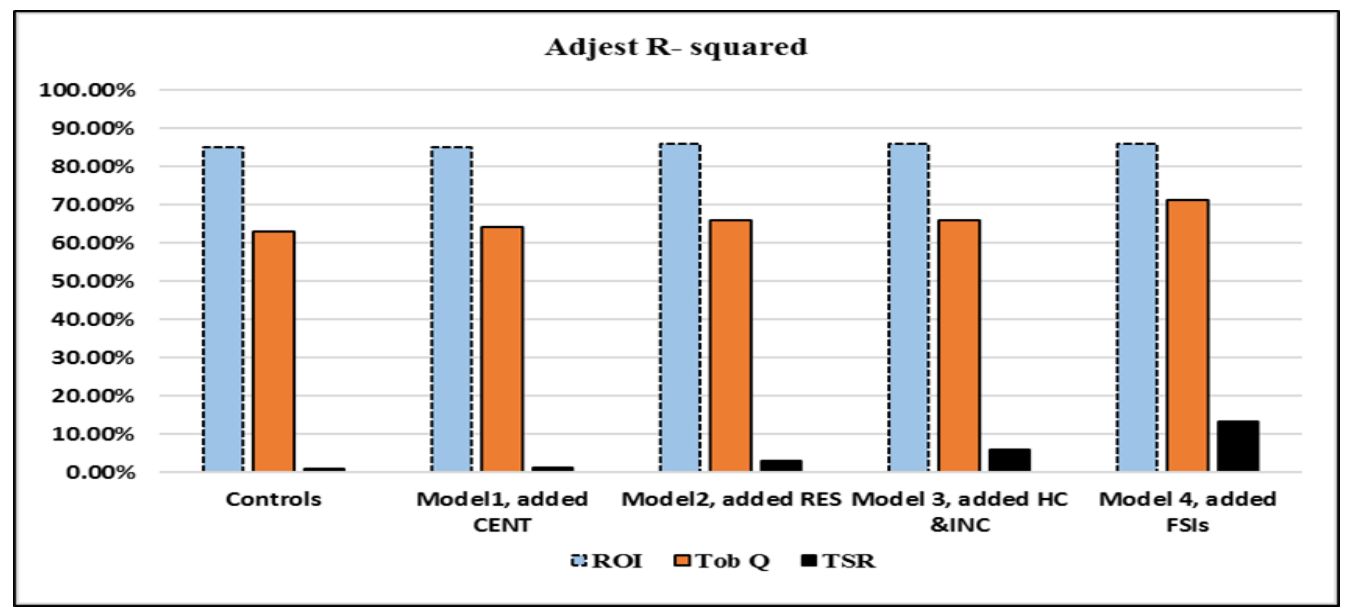

Figure 3: Adjusted R-squared for Models 1 to 4

The second objective of this study is to determine the effects of CSC's components on company efficiency. To achieve this goal, the regression analysis is done for CSC's components based on control and independent. The sub sample of Size is used by net sales as a proxy for company size. The median point is as cut off point between large and small companies. Remove variable of company size from the full sample regression equation is the only salvation form for regression equation. Table 9 illustrates The Hypotheses test results using Size of company as control variables are illustrated in Table 9. The results show the Hypothesis 3 (Human Capital influence) and Hypothesis 5 (Financial Soundness influence) are accepted. The rejected Hypotheses include Hypothesis 1 (Centrality influence), Hypothesis 2(Absorptive Capacity 
influence) and Hypothesis 4 (Internal Capital influence). The rejected Hypotheses showed significant predictions but in the opposite direction. One of the deference points between large and small companies is in Total Shareholder Return, where Total Shareholder Return is accepted by Financial soundness for large companies and it is rejected by Internal capital and Centrality for large and small companies. It should be noted that Total Shareholder Return is not accepted nor rejected by Financial soundness. The deferent points between large and small companies are that Financial soundness also positively predicts Total Shareholder Return and Internal capital negatively predicts Total Shareholder Return for small companies and for large companies; Centrality negatively predicts performance of Total Shareholder Return. Research intensity and Internal capital are both rejected by large and small companies and they are not consistent with Hypotheses 2 and 4. Hypothesis 2 that pointed out to effects of Research intensity in company efficiency, is rejected by small and large companies. The reason for rejected can be attributed to the negative view of Research intensity that is considered as pure cost and it has negative impact on Return On Investment.

Accountants believe that, Research intensity is classified in expenses and therefore those companies with spending more amounts on research and development are faced with lower amounts of Return On Investment. The lack of positive effect associated with Tobin Q or Total Shareholder Return, not suggested Research intensity as an intangible that contribute to measuring market-related of company efficiency. These results of Research intensity are consistent with value relevance The results of studies that conducted on expenditure of research and development (Chan, Lakonishok, \& Sougiannis, 2003; Lev \& Sougiannis, 1999) are consistent with the results of Research intensity in this study. In other hand, development and research and spending on Research intensity are not reflected in share values (Aboody \& Lev, 1998).

Table 9: Hypothesis Test Results, Sub Sample of Large and Small Company

\begin{tabular}{|c|c|c|c|c|}
\hline Hypothesis & $\begin{array}{l}\text { Performance } \\
\text { Indicator Predicted }\end{array}$ & $\begin{array}{l}\text { Large } \\
\text { Company }\end{array}$ & $\begin{array}{l}\text { Performance Indicator } \\
\text { Predicted }\end{array}$ & Small Company \\
\hline $\mathrm{H}_{1}$ : & & Rejected & & Rejected \\
\hline $\mathrm{H}_{2}$ : & & Rejected & & Rejected \\
\hline $\mathrm{H}_{3}$ : & TSR, ROI & Accepted & ROI , TSR & Accepted \\
\hline $\mathrm{H}_{4}:$ & & Rejected & & Rejected \\
\hline $\mathrm{H}_{5}$ : & ROI , Tobin Q & Accepted & ROI , TSR, Tobin Q & Accepted \\
\hline
\end{tabular}

Profitability is one of the control variables and introduced because of the profitable and lossmaking companies in the sample. Table 10 shows the Hypotheses test results using sub sample of profitability and loss-making companies. The only difference between large / small companies in Size sample and Profitability sample is the Hypothesis 1, where the positive association of Centrality is accepted in profitability sample. The significant association for Hypotheses 2 and 4 are found in the opposite direction, like the previous sample. The control variables include both company Size and Profitability have positive influence on Return On Investment and both have negative influence on Tobin Q. Total Shareholder Return is an exception because, here it is negatively associated with small loss-making companies. This can probably be a reflection of small companies' vulnerability in positions of loss making and they are usually weak to sustain market valuation growth or substantial dividends. 
Table 10: Hypothesis Test Results, Sub Sample of Profitability and Loss-making Company

\begin{tabular}{|c|c|c|c|c|}
\hline Hypothesis & $\begin{array}{l}\text { Performance } \\
\text { Indicator Predicted }\end{array}$ & $\begin{array}{l}\text { Profitability } \\
\text { Company }\end{array}$ & $\begin{array}{l}\text { Performance Indicator } \\
\text { Predicted }\end{array}$ & $\begin{array}{l}\text { Loss-making } \\
\text { Company }\end{array}$ \\
\hline $\mathrm{H}_{1}$ : & Tobin Q & Accepted & Tobin Q & Accepted \\
\hline $\mathrm{H}_{2}$ : & & Rejected & & Rejected \\
\hline $\mathrm{H}_{3}$ : & TSR & Accepted & ROI , TSR & Accepted \\
\hline $\mathrm{H}_{4}:$ & & Rejected & & Rejected \\
\hline $\mathrm{H}_{5}$ : & ROI, Tobin Q & Accepted & ROI, TSR, Tobin Q & Accepted \\
\hline
\end{tabular}

The last control variable in this study is Industry sub-sector. it is developed to test difference of potential within the IT sector as a whole. Split of the sample approximately divides a sub-sector to computer software and related services with the other hardware and non-software services. Table 11 illustrates the Hypotheses test results using the control variable as software and nonsoftware companies.

Table 11: Hypothesis Test Results, Sub Sample of Software and Non-Software Company

\begin{tabular}{lclcl}
\hline Hypothesis & $\begin{array}{l}\text { Performance } \\
\text { Indicator Predicted }\end{array}$ & $\begin{array}{l}\text { Software } \\
\text { Company }\end{array}$ & $\begin{array}{c}\text { Performance Indicator } \\
\text { Predicted }\end{array}$ & $\begin{array}{l}\text { Non-software } \\
\text { Company }\end{array}$ \\
\hline $\mathrm{H}_{1}:$ & Tobin Q & Accepted & & Rejected \\
$\mathrm{H}_{2}:$ & & Rejected & & Rejected \\
$\mathrm{H}_{3}:$ & TSR , ROI & Accepted & ROI, TSR & Accepted \\
$\mathrm{H}_{4}:$ & Rejected & ROI & Accepted \\
$\mathrm{H}_{5}:$ & TSR , ROI , Tobin Q & Accepted & ROI, Tobin Q & Accepted \\
\hline
\end{tabular}

The accepted is found for Hypothesis 4 for Internal capital. Hypothesis 4 about influence of Internal capital accepted Return On Investment for non-software companies that it is the main difference with previous samples. The reason of this difference may be attributed to relation of non-software companies with manufacturing computer hardware companies. From the view of management in quality system, Internal capital has origin in manufacturing situations like computer hardware manufacturer. However, the significance of association is low $(\mathrm{p}<0.05$; one-tail test).

Summary of the results of regression test between accounting variables as dependent variables and CSC components as independent variables are illustrated in Table 12.

Table 12: General Result Pattern

\begin{tabular}{llllll}
\hline Efficiency & \multicolumn{5}{l}{ CSC Components } \\
\cline { 2 - 6 } Variables & CENT & RES & HC & INC & FSIs \\
\cline { 2 - 6 } ROI & & - & + & & + \\
Tobin Q & + & & & - & + \\
TSR & - & & + & - & + \\
\hline
\end{tabular}

Summary of the results by regression test on the sub-sample is illustrated in Table 12 for the discussion about the results for Hypotheses of the study. The results of full sample show the accepted for Hypotheses 1, 3, 5 and rejected for Hypotheses 2, and 4. The only accepted subsample for Hypothesis 4 is Return On Investment in non-software companies, and Hypothesis 
4 is rejected by other sub-sample. Hypothesis 4 for Return On Investment in the non- software industry is accepted with low and marginal significance and it does not have considerable importance for accepting the other 6 rejected patterns of sub-samples that are found with Hypothesis 4 against company efficiency. The positive association of Centrality is found only for efficiency of Tobin Q and this probably suggested that Centrality like Tobin Q is considered as a predictor rather than as a historical efficiency measure. Activity of company to improve the position in the market in order to a better position in the market for future and it accordingly with literature of CSC that states investment on Social capital is as a strategic activity in long term (Burt, 2003; Burt \& Guilarte, 2002).

As noted, the third objective of this study is to determine the interaction effects of variables on company efficiency. Post Hoc Analysis is conducted because of the unexpected results that reported in the previous sections. The unexpected results from prior results or anticipated are the reasons to explore a number of interaction effects that are described. In order to find an interaction, researcher must have a factorial design, in which the two or more independent variables are crossed with one another so that there are observations at every combination of levels of the two independent variables. The aim of discovery of variables with interaction effects is provide the explanation for identify of rejected Hypotheses. The selected senior interaction variables are the creator for the senior selected in investigation. It is important that the all selected variables are ranked and not raw variables. The base for choosing the models for interaction effects is related to F-statistic and Adjusted R-squared. Therefore, the achieved significant ratio for models include F-statistic to the $\mathrm{p}<0.01$ level, with adjusted R-squared highest for Return On Investment prediction (0.846) and lowest for Total Shareholder Return (0.160). Base on the control variables, $\mathrm{P} \& \mathrm{~L}$ is significant for all efficiency measures, SIZE is for efficiency measures of Return On Investment and Tobin's q and IND is with weakest significance and it is significant only for Return On Investment. The regression tests for each of the three sub-samples of large / small companies, profitable / loss-making companies, and software / non-software companies were conducted in the previous regression tests. The results of regression tests in Table 12 illustrated that Financial soundness is the most predictive component of CSC and it has the most effects on company efficiency, hence, one of the most important elements in models of interaction effects is Financial soundness. Therefore, the interaction effects of Financial soundness with other elements of CSC on company efficiency can be as a significant impact. Base on the results of CSC and its components effects on company efficiency, the multiple regressions are used to test the interaction effects between independent variables. Base on the study of Aiken \& West (1991), calculating of interaction effects is not possible by simple linear regression, because it is an example of complex text, therefore they presented a regression model for calculating interaction effects. the chosen variables with interaction effects are illustrated in Table 13.

Table 13: Interaction Variables

\begin{tabular}{|c|c|}
\hline & Interaction Variables \\
\hline FSIs $_{x}$ CENT & Financial soundness interaction with centrality \\
\hline FSIs ${ }_{\mathbf{x}}$ RES & Financial soundness interaction with research intensity \\
\hline FSIs $_{\mathbf{x}} \mathrm{HC}$ & Financial soundness interaction with human capital \\
\hline FSIs ${ }_{x}$ INC & Financial soundness interaction with internal capital \\
\hline $\mathrm{CENT}_{\mathbf{x}} \mathrm{HC}$ & Centrality interaction with human capital \\
\hline
\end{tabular}


The effects of Social capital on high growth has been done using interaction analysis the effects of Absorptive Capacity on market centrality has been done using interaction analysis (Tsai, 2001). The interaction effects between variables on a dependent variable when added as an additional independent variable into regression equation, is tested by interaction analysis. It is predicted that interaction of Financial soundness with other components of CSC can have a significant effect on company efficiency. Therefore, Financial soundness play an important role in models of interaction effects.

Base on Hypothesis 1 about positive effects of Centrality on company efficiency, investigations argued a negative relation between Centrality and Total Shareholder Return. The Hypothesis is that Financial soundness might act as moderating effect on this relationship. Therefore, the plot considered the negative relationship between Centrality and Total Shareholder Return and aim of the plot is to examine the role of Financial soundness in this negative relationship. The interaction plot between Centrality, Total Shareholder Return, and Financial soundness with regression test equation is as firs plot. The main effects shown the negative association of Centrality with Total Shareholder Return for large or profitable companies, and the interaction effect with Financial soundness was negative for Total Shareholder Return. The plot 1 Shows that the direction of association will be changed from low to high of Financial soundness. This result help to suggestion that Centrality help to Total Shareholder Return for companies in poor financial shape, but can be a constraint for large or profitable companies in effect reducing Total Shareholder Return. This is consistent with the earlier conjecture that large or profitable companies are potentially constrained by high Centrality.

Base on Hypothesis 2 about positive effects of Research intensity on company efficiency, investigations argued a negative relation between Research intensity and Total Shareholder Return.

The Hypothesis is that Financial soundness might act as moderating effect on this relationship. Therefore, the plot 2 considered the negative relationship between Research intensity and Total Shareholder Return and aim of the plot is to examine the role of Financial soundness in this negative relationship. The plot also illustrated that the negative effects are not sustain in the high levels of Financial soundness, therefore, the role of Financial soundness as reverse or moderate on the negative effects of Research intensity on Total Shareholder Return. This role of Financial soundness can be effective by companies in market that have enough financial resources to pay the investments on Research intensity.

The plot 3 investigated the negative interaction effect of Financial soundness and Human capital on Total Shareholder Return. In addition, a strong positive relationship was found between Human capital and Total Shareholder Return for most scenarios. Therefore, the negative interaction effect with Financial soundness is unexpected. Base on the previous results, despite the strong positive relation between Human capital and Total Shareholder Return, coefficient for interaction between Human capital and Financial soundness is negative. It seems the stranger influence of Human capital on Total Shareholder Return with poor Financial soundness companies, but become weaker as Financial soundness improved. Although the relationship remains positive for all levels of Financial soundness, but it is an explain of the negative coefficient for the interaction term. Therefore, the above results suggested the increasing in 
Human capital could be seen as the best way for improving the poor financial position and rewards in the marketplace.

Base on Hypothesis 4 about positive effects of Internal capital on company efficiency, investigations argued a negative relation between Internal capital and Tobin Q. The Hypothesis is that Financial soundness might act as moderating effect on this relationship. Therefore, the plot 4 considered the negative relationship between Internal capital and Tobin Q and aim of the plot is to examine the role of Financial soundness in this negative relationship. The negative main effects of Tobin Q and Total Shareholder Return was shown in the interaction plot 4. Although, the interaction term of Financial soundness and Internal capital was positive. In other words, the companies with strong Financial soundness could not have the negative relationship.

The investigation of Florin (2003) has replicated in plot 5 for the effects of Centrality on the relationship between Human capital and company efficiency on Total Shareholder Return. The plot shows for all levels of Human capital, companies with lower Centrality can achieve higher level of Total Shareholder Return efficiency than companies with high level of Centrality, however, the difference are not large. It is expected, the higher level of connection, helps to Company's human resource for achieving the new financial resources. As noted to the negative relationship between Centrality and Total Shareholder Return for large and profitable companies, this would not be necessarily being expected for building Total Shareholder Return.

The summary results after interaction effects survives are illustrated in Table 15.

The results of interview are illustrated in Table 14 on the $20 \%$ of the sample companies.

Table 14: The Summary Results of Interview

\begin{tabular}{|c|c|c|c|c|c|c|c|c|c|c|c|}
\hline \multirow[t]{2}{*}{ Influence of CSC and Its Components } & \multicolumn{11}{|c|}{ Selected Companies for Interview } \\
\hline & A & B & $\mathrm{C}$ & $\mathrm{D}$ & $\mathrm{E}$ & $\mathrm{F}$ & $\mathrm{G}$ & $\mathrm{H}$ & $\mathrm{I}$ & $\mathrm{J}$ & $\mathrm{K}$ \\
\hline CSC has Influence on company efficiency & + & + & + & + & + & + & + & + & + & + & + \\
\hline $\mathrm{HC}$ has Influence on company efficiency & + & + & + & + & + & + & + & + & + & + & + \\
\hline INC has Influence on company efficiency & - & - & + & - & & - & - & & - & + & \\
\hline CENT has Influence on company efficiency & + & + & & + & & - & & & + & + & - \\
\hline RES has Influence on company efficiency & - & - & + & - & + & & + & + & - & - & + \\
\hline FSIs has Influence on company efficiency & + & + & + & + & + & + & + & + & + & + & + \\
\hline
\end{tabular}

Table 15: Summary Results of Interaction Effects (Accepted $=+$ and Rejected $=-$ )

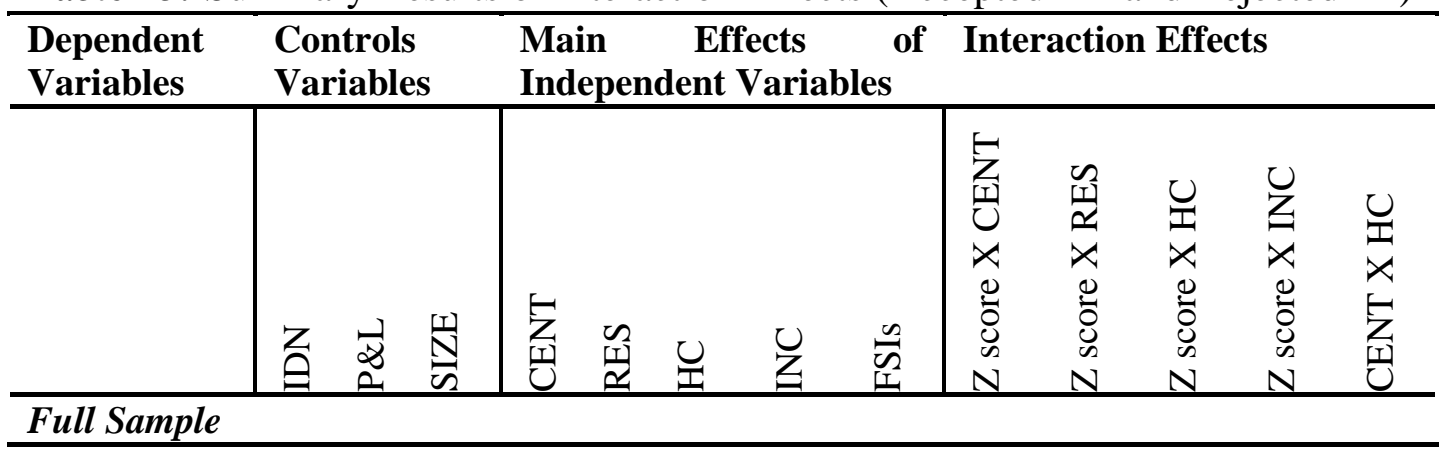




\begin{tabular}{|c|c|c|c|c|c|c|c|c|c|c|c|c|c|}
\hline ROI & + & + & + & & - & & & + & & & - & + & \\
\hline Tobin's Q & & + & - & + & & & & + & + & - & & + & \\
\hline TSR & & + & - & + & & & & + & + & - & & + & \\
\hline \multicolumn{14}{|c|}{ Large Company } \\
\hline ROI & + & + & + & & - & & & + & & & - & + & \\
\hline Tobin's Q & + & & & & & & & + & + & & & & \\
\hline TSR & & + & & & & + & & & & & - & & \\
\hline \multicolumn{14}{|c|}{ Small Companies } \\
\hline ROI & & + & & & & + & & + & & & & & \\
\hline Tobin's Q & & + & & & & & & + & & & & + & - \\
\hline TSR & & + & & & & & - & + & - & + & - & & \\
\hline \multicolumn{14}{|c|}{ Profitable Companies } \\
\hline ROI & + & & + & - & & & & + & + & & & & \\
\hline Tobin's Q & + & & - & + & & & - & + & + & - & + & + & \\
\hline TSR & - & & & & & & - & + & - & & & + & + \\
\hline \multicolumn{14}{|c|}{ Loss-making Companies } \\
\hline ROI & & & + & & & + & & + & & & - & + & + \\
\hline Tobin's Q & & & - & + & & & & + & & - & & + & \\
\hline TSR & & & & & & + & & + & - & + & - & & \\
\hline \multicolumn{14}{|c|}{ Software Industry Companies } \\
\hline ROI & & + & + & & & & & + & & + & & & \\
\hline Tobin’s Q & & + & - & + & & & & + & & - & & + & \\
\hline TSR & & + & & & & + & - & + & - & + & - & + & + \\
\hline \multicolumn{14}{|c|}{ Non-software Industry Companies } \\
\hline ROI & & + & + & & - & + & + & + & & & & + & \\
\hline Tobin's Q & & + & - & & & & - & + & + & - & & & \\
\hline TSR & & + & & & & + & & & & + & - & & \\
\hline
\end{tabular}

\section{CONCLUSIONS \& RECOMMENDATIONS}

The results of the hypotheses tests approved the three hypotheses support of the five hypotheses. The positive relationship between Centrality, Human capital and Financial soundness with company efficiency were accepted, but the hypothesized positive relationship between Research intensity and Internal capital with company efficiency were ejected. The rejected of two hypotheses together with similar studies results, were further analyzed for interaction effects that were achieved for the failed hypotheses. The significant achieved results are mentioned in following.

- CSC has an important influence on company efficiency and prove the value relevant for all measures of company efficiency. 
- Total Shareholder Return was the largest differential in explanatory power for CSC and least for Return On Investment, and suggested that CSC is more important for efficiency measures of market-based.

- For future prediction of company efficiency, Financial soundness is the most critical component of CSC and the exception is only for large, profitable or non-software companies, when predicting Total Shareholder Return, where other factors appear to have more influence.

- The positive impact of Centrality is only in Tobin's q. This suggested that Centrality is as a future strategic positioning factor for the company and the benefit from higher level of Centrality is significant for software industry.

- The experience of negative impacts for a company with more connection is created most for large or profitable companies and especially for companies in non-software sector, and despite the Financial Soundness, negative impacts of Total Shareholder Return with high level of Centrality can be created for these companies.

- The relationship of Human capital with Return On Investment and Total Shareholder Return is consistently positive in all scenarios of company size, profitability or industry sector.

- For companies with poor finances, investment in Human capital is more attractive. Although the investments in Human capital are beneficial and for lossmaking companies this benefit is most in terms of Total Shareholder Return and Return On Investment, but investments in Research and Development and Internal capital is harmful for these companies, where Total Shareholder Return can decrease.

- The relationship between investments in Research and Development and company efficiency is negative and Research and Development has a negative impact on Return On Investment. This result suggests that Research and Development is only as an expense without the positive impact in market efficiency.

- The suggestion also is that for the sample used, Research and Development is not as a good Absorptive Capacity proxy.

- Internal capital investment has negative effects on company's Tobin Q and efficiency of Total Shareholder Return.

- Financial soundness can act as a mediator and potentially reverse the negative relationship of Research and Development and Internal capital with company efficiency.

\section{REFERENCES}

[1] Aboody, D., and Lev, B. The Value Relevance Intangible: The Case of Software Capitalization. Journal of Accounting Research, 36, 1998, 161-191.

[2] Aiken, L. S., and West, S. G. Multiple Regression: Testing and Interpreting Interactions. Newbury Park: 1991, Sage.

[3] Arregle, L. J., Sirmon, D. G., Hitt, A. M., and Webb, J. W. The Role of Family Influence in Firms' Strategic Responses to Threat of Imitation. Journal of ET\&P, 32 (6), 2008, 979 998.

[4] Borgatti, S. P., and Foster, P. C. The Network Paradigm in Organizational Research: A Review and Typology., Journal of Management, 29 (6), 2003, 991-1013.

[5] Borgatti, S. P., Jones, C., and Everett, M.G. Network Measures of Social Capital. CONNECTIONS, 21(2), 1998, -36. 
[6] Borgatti, S. P. (Ed.) A SOCNET Discussion on the Origins of the Term 'Social Capital'. Connections, vol. 21 (2), 1998, 37-46.

[7] Burt, R., Guilarte, M., Raider, H., and Yasuda, Y. Competition, Contingency, and External Structure of Markets. Advances in Strategic Management, 19, 2002, 167-217.

[8] Burt, R. S. The Network Structure of Social Capital. Research in Organizational Behavior, 22, 2002, 345-423.

[9] Burt, R. The Social Structure of Competition. In Rob Cross, A. Parker, \& L. Sasson (Eds.), Network in the Knowledge Economy, 2003, 13-56. New York: Oxford University Press.

[10] Chan, L. K., Lakonishok, J., and Sougiannis, Th. (2003). The Stock Market Valuation of Research and Development Expenditures, in Hand, J. R. M./ Lev, B. (Hrsg.), Intangible Assets. Values, Measures and Risks, Oxford 2003, S. 387-414.

[11] Eidleman, G. Z-Scores - A guide to Failure Prediction, The CPA Journal Online. 1995, http://www.nysscpa.org/cpajournal/old/16641866.htm (accessed 8/11/05).

[12] Florin, J., Lubatkin, M., and Schulze, W. A Social Capital Model of High Growth Ventures. Academy of Management Journal, 46(3), 2003, 374-384.

[13] Gallagher, C., and Miller, p. New Fast-growing Companies Create Jobs. Long Range Planning. 24(1), 1991, 96-101.

[14] Gulati, R., and Gargiulo, M. Where Do Inter Organizational Networks Come from? Journal of AJS, 104(5), 1990, 1439-93.

[15] Han, D., and Han, I. Prioritization and Selection of Intellectual Capital Measurement Indicators Using Analytic Hierarchy Process for the Mobile Telecommunications Industry. Expert Systems with Applications, 26, 2004, 519-527.

[16] Hirigoyen, M. F. Political Strategies of Organizations. Journal of Lavoisier, 41, 2009, 252.

[17] Hongi, B., Lerner, M., and Raban, Y. Social Capital and the Linkages of High Tech Companies to the Military Defense System. Small Business Economics, 27(4), 2006, 419 437.

[18] Johanson, U. Capital Market Actors Ambivalent to Information about Certain Indicators of Intellectual Capital. Accounting, Auditing \& Accountability Journal, 16(1), 2003, 31 38.

[19] Leenders, R., and Gabbay, S. (Eds.). Corporate Social Capital and Liability. Boston: 1991, Kluwer Academic Publishers.

[20] Lev, B., and Sougiannis, T. Penetrating the Book-to-Market Black Box. Journal of Business and Finance Accounting, 26, 1999, 419-449.

[21] Lev, B. Seeing believes: A Better Approach to Estimating Knowledge Capital, 1999, $\mathrm{CFO}$.

[22] Lev, B. Intangibles: Management Measurement and Reporting. Washington, D.C.: 2001, Brookings Institution Press.

[23] Norton, D. P. Intangible Assets and Value Creation. German Newsletter Controlling \& Finance.

[24] Orlitzky, M., Schmidt, F., and Rynes, S. Corporate Social and Financial Performance: A Meta-Analysis. Organization Studies, 24, 2003, 403-441.

[25] Petty, R., and Guthrie, J. Intellectual Capital Literature Review: Measurement, Reporting and Management. Journal of Intellectual Capital, 1(2), 2000, 155-176. 
[26] Pike, S., and Roos, G. Mathematics and Modern Business Management. Journal of Intellectual Capital, 5(2), 2004, 243-256.

[27] Putman, R. Bowling Alone: America's Declining Social Capital. Journal of Democracy, 6(1), 1995, 65-78.

[28] Ricceri, F. Forthcoming. Intellectual Capital and Knowledge Management: 2008, Routledge.

[29] Saunders, M., Lewis, P. and Thornhill, A. Research Methods for Business Students. London: Prentice Hall. 2007, 4th Ed.

[30] Sekaran, U. Research Methodology for Business. Selemba Four, Jakarta, 1, $2000,4$.

[31] Shanley, M., and Fombrun, C. What's in a Name? Reputation Building and Corporate Strategy. Academy of Management Journal, 33(2), 1990, 233-256.

[32] Sveiby, K., and Risling, A. Kunskapsforetaget (the Know-How Company). Malmo: 1986, Liber.

[33] Sveiby, K. E. The New Organizational Wealth, Managing \& Measuring KnowledgeBased Assets: Berret-Koehler Publishers, 1997, Inc.

[34] Tsai, W. Knowledge Transfer in Intra-Organizational Networks: Effects of Network Position and Absorptive Capacity on Business Unit Innovation and Performance. Academy of Management Journal, 44(5), 2001, 996-1004.

[35] Wann, Y. W., Man, L. C., and Chih, W. C. Promoting Innovation through the Accumulation of Intellectual Capital, Social Capital, and Entrepreneurial Orientation. Journal of R\&D Management, 38(3), 2008, 265-277.

[36] William, H. A. Johnson. an Integrative Taxonomy of Intellectual Capital. Journal of Technology Management, 18, 2004, 5-8.

[37] Zambon, S., Abernethy, M., Wyatt, A., Bianhi, P., Labory, S., and Lev, B. Study on the Measurement of Intangible Assets and Associated Reporting Practices. Commission of the European Communities, 2003. 